\title{
Analysis of potate quality: In vitro versus clonal propagation
}

\author{
Y. Fedoruk*, M. Grabovskyi, L. Pravdyva, N. Ostrenko, T. Lozinska, N. Fedoruk, T. \\ Grabovska, S. Obrazhyy, S. Hornovska, N. Prisjazhnjuk
}

\author{
Bila Tserkva National Agrarian University, Bila Tserkva, Ukraine \\ 8/1 Soborna Sq., Bila Tserkva, Kyiv Region, 09117, Ukraine \\ *Corresponding author E-mail: fedoruky 4@ukr.net
}

\section{Received: 15.01.2020. Accepted: 15.02.2020}

\begin{abstract}
Potato, one of the most important food crops in the world, is susceptible to viruses, which reduce its yield and production efficiency. The resistance of potatoes to viral infection is an essential factor in the preservation of the variety's productive qualities. In addition, there are several ways of selection for recovering and obtaining the initial seed material that is free from viruses for further reproduction in the seed growing of potatoes. It should be noted that in the literature the issues of medium-late potato varieties resistance to viral diseases in the Forest-Steppe zone of Ukraine are not fully covered, which has become the subject of our research. In our studies we used the material obtained by the method of improving selections, as well as using thermotherapy and apical meristem culture. Over the years of reproduction both meristematic and seed material from improving selections, the virus infestation in plants wasn't changed significantly, provided that all seed growing events were observed. It has been proven that the yield of super-super-elite of Lybid variety is not significantly changed depending on the method of obtaining the initial material. The variety Gorlitsa has higher yield in the plantations formed by clonal propagation. It has been established that the yield of variety Lybid super-elite varies, but not significantly, depending on the method of obtaining the initial material. The variety Gorlitsa has a higher super-elite yield when using the initial material from clonal propagation in breeding nurseries with use of improved selections. Significant influence on the manifestation of the sign, both in the cultivation of super-super-elites and super-elites, has the weather conditions of the year and the biological characteristics of the variety. In 2017, the highest yield of tubers was obtained at Gorlitsa $-3.74 \cdot 10^{4} \mathrm{~kg} \mathrm{ha}^{-1}$, at Lybid the lower yield was $2.43 \cdot 10^{4} \mathrm{~kg} \mathrm{ha}^{-1}$. In 2018 , the highest yield of tubers was formed by Lybid variety $-3.50 \cdot 10^{4} \mathrm{~kg} \mathrm{ha}^{-1}$, and the lowest was byt Gorlitsa variety $-2.56 \cdot 10^{4} \mathrm{~kg} \mathrm{ha}^{-1}$.
\end{abstract}

Keywords: Potato; Viruses; Varieties; Improving selection; Meristematic propagation; Yield, Propagation and seed growing

\section{Introduction}

Potato is the most important agricultural crop, which has high adaptability, plasticity and potential productivity. It is cultivated in 130 countries of the world; it is a strategic product for many of them (Saynakova et al., 2018, Vakhnyi et al., 2018). This crop ranks fourth in the world after corn, wheat and rice by production volume (Afonnikov et al., 2018). Among the shortcomings, this is one of the most crops affected by diseases and pests.

The yield and quality of potatoes depend on the infection rate with a number of pathogens, including bacteria, fungi, viruses and viroids. Viral infection can cause considerable damage to this food crop (Makarova et al., 2017; Ibragimova et al., 2018).

It has been established that it is the viruses that reduce the productive qualities of tubers in $90 \%$ cases and only $10 \%$ caused by unfavorable environmental conditions, plant nutrition problems and other negative factors (Onishchenko, 1996; Frolova, 1971).

According to the latest reports, there are more than 30 viral, viroid and mycoplasma diseases identified in potatoes (Trofimets, 1990; Reifman et al., 1996). Among the identified viruses found on potatoes, XBK, SBK, MBK, YBK, LBK cause significant harm to the potato industry (Ambrosov, 1975, Blotskaya, 1983; Sheludko, 1970).

Potato is propagated vegetatively, and therefore pests are dangerous not only for the plantings of the current year: being preserved in subsequent reproductions, they lead to increased losses and lower product quality (Rogozina, Khavkin, 2017).

It is possible to solve this problem by creating virus-resistant varieties (Kim I.V., et al., 2016). However, it should be noted that the creation varieties with complex disease resistance is one of the most difficult, but priority directions in the selection of potatoes (Gavrilenko et al., 2018, Erenkova et al., 2018).

Virus-resistant potato varieties reliably ensure the realization of genotypic potential production in different years, as well as the effectiveness of supporting selection in the virus-free seed production system (Mayshchuk, 1995). Different resistance of varieties to individual viruses is characteristic of both the material obtained by selection and the healthier using apical meristem culture (Vermenko, 1992). The difference between varieties obviously determines how quickly a variety loses its productive qualities as a result of the intense accumulation of viruses in tubers (Vermenko, Zyvertok, 1988).

Thus, the resistance of varieties to viral infection is a significant factor in maintaining the productive qualities of a variety in the process of its use. When reproducing potatoes, one should take into account varietal characteristics of resistance to viral diseases. It should be noted that in the literature the issues of sustainability of certain middle-late potato varieties against viral diseases in the Forest-Steppe zone of Ukraine are not fully covered, that's why we chose them as the subject of our research.

There are several ways in the seed potato production to select recovery and to obtain seed-free material from viruses for further reproduction. In primary seed production, selection is used as a method of maintaining the potential qualities of potato varieties and keeping them healthy. Types of propagation are varied and consist of negative mass selection (phytocleaning) and improving propagation (tuberous, nested and clonal). Mass selection is carried out on varietal crops, which have the best conditions for growing potatoes. At least two cleanings from diseased plants and impurities of other varieties are preliminarily carried out 
(Onishchenko, 1996). Improving selection is carried out on the characteristics of the ground part of the bush with the next selection of tubers' quality during harvesting (Kononuchenko, Molotsky, 2002; Ostapenko, 1990). Tuber propagation efficiency increases if it is carried out after thorough healing cleansing (Baranova et al., 1990).

The most common and effective in practical seed production, in particular elite, is clonal propagation. It allows substantially eliminating viral, fungal and bacterial diseases (Zykin, 1976). It also makes it possible for a variety to maintain high yields, grain size, and control disease incidence for a long time. This property of clonal propagation is also typically for the improved healthy seed material by biotechnological method (Mayshchuk, 1991; Mayshchuk, Sadovsky, 1995; Timoshenko et al., 1991).

When using biotechnology-improved seed material, the propagation of clones is carried out after evaluating plants for a latent viral infection, using laboratory methods for determining viruses. In particular, a high effect is obtained in the case when the selection is carried out in a nursery laid by healthy tubers and plants in vitro (Svertoka, 1993). However, some researchers believe that clonal propagation for the viral infection prevention applies only to certain varieties and viruses (Kononuchenko, Molotsky, 2003). It is also noted in literature that with various methods of recovery, clonal propagation can only be used as an auxiliary measure (Shmygla, 1995). Thus, with the prevalence of seed in the nursery above $50 \%$, the selection of healthy plants may be ineffective; therefore, it is necessary to use methods of healing and clonal micropropagation. With less than $20 \%$ material damage, selection will be quite effective, while the costs of obtaining healthy plants will be several times lower than with clonal reproduction (Loginova, 1986). Therefore, the use of improving selections requires consideration of the various factors influence in order to obtain positive results. The study of these factors focuses on the establishment of tuber offspring productive indicators, however, such components as the genotype of the variety and improved seed material by the culture method of the apical meristem, as well as its further use in the original seed production, are not well understood. The effectiveness of the using seed material obtained by application meristemtissue culture has been proven in many research works and confirmed by the practice of domestic and foreign potato growing (Bundling, 1998; Reznik, 1997). For reproduction of the improved apical meristem of the potato by thermotherapy and culture, clonal micropropagation is mainly used.

Clonal micropropagation provides a disease-free initial material in sufficient quantities for the needs of the primary seed production units. They use both laboratory methods (micropropagation in vitro) and methods of accelerated propagation of virus-free plants, mainly for the production of mini-tubers in cultivation structures or in the field. Micropropagation is carried out by taking nodal cuttings of plants obtained from meristem under artificial conditions on a special nutrient medium. As a result, very high breeding rates are achieved -1 million plants in 120 days (Trofimets, 1989). Plants regenerated after meristems thermotherapy are free from the most common and harmful pathogens of potatoes, primarily viruses. As a result of this, actively revitalized seed material is noted at the first stages of its use with enhanced productive qualities (Kononuchenko, Molotsky, 2003; Shmygla, 1989).

The first country that transferred to receive all the planting material of potatoes by the method of tissue culture was Denmark. Since 1976, a program was carried out for 10 years in this country, after which all planting material was brought into the requirements of the European market. The tissue culture method is the basis of the seed production process in China, in Japan potato recovery from viruses by this method has been carried out since 1964 (Kiselev et al., 1990). Thus, the analysis of literature indicates a multifactorial dependence of the potato productivity and therefore, the purpose of the work is to study the presence of a viral infection in the seed material in the process of reproducing various forms of initial material and to establish its productive and seed qualities depending on the recovery method and the variety.

\section{Material and Methods}

Experimental work was carried out during 2016-2018 in the conditions of Bila Tserkva National Agrarian University's bio-station; these lands are located in the zone of the Central Forest-Steppe of Ukraine. Technology of cultivation is typical for the Central Forest-Steppe zone. Soil and climatic conditions are typical for this zone. The land area was $25 \mathrm{~m}^{2}$, repetition - four times. Field studies were conducted according to generally accepted methods (Armor, 1985).

In the course of the research, surveys, observations and analyzes were carried out in accordance with the methodological recommendations (Kononuchenko, 2012).

The field experiment scheme includes following factors:

\section{Factor A. Varieties:}

1. Mid-season - Lybid;

2. Mid-season - Horlitsa.

\section{Factor B. Ways of obtaining seed material:}

\section{Improving selection;}

2. Meristem propagation.

For the seed material formation we used clones from visually healthy plants selected on crops, where breeding varieties of Potato Breeding Institute were propagated, as well as clones from visually healthy plants from the first tuber reproduction sites in vitro plants produced by the method of meristem tissue culture. This material was classified as obtained by the method of improving selections and with the use of thermotherapy and apical meristem culture. Further testing conducted by the method of superposition, namely reproduction of initial seed material batch in research years, which makes it possible to observe a change in the quality indicators and yield. Selection of seed material was carried out at the beginning of the dying of the foliage.

The combined material for each of these nurseries was tested in compliance with seed-growing activities in accordance with the requirements for reproduction of the original seeds and elite. During the vegetation period, visual assessments were made of the extent of damage by viral diseases and the presence of viruses by the method of dropping agglutination on glass. For serological diagnosis we used antiviral sera specific to $\mathrm{XBK}, \mathrm{MBK}$ and $\mathrm{SBK}$, manufactured at the Institute of Agricultural Microbiology of the Ukrainian Academy of Agrarian Sciences (Chernigov) were used. To determine the presence of viral diseases, all plants at the site were visually inspected 1-2 times a week until they reach a height $10-12 \mathrm{~cm}$. If there were signs of leaf rolling, wrinkled, striped mosaic and other diseases, the plants were dug out and removed outside the field. Accounting of the harvest is common, from each plot and each repetition with the definition of the structural composition. Statistics of the obtained results were performed using the Microsoft Excel software. 


\section{Results and Discussion}

In 2016, clones and the tuber material that multiplied by the generally accepted seed-growing methods were tested, with obligatory removal of the bushes affected by diseases. Seed material from healthy plants was selected for the next test. Varieties that were used for research on plantings with meristem material had less plants affected by viral diseases, compared to plantations with material from improved selection where breeding material was propagated (Figure 1).

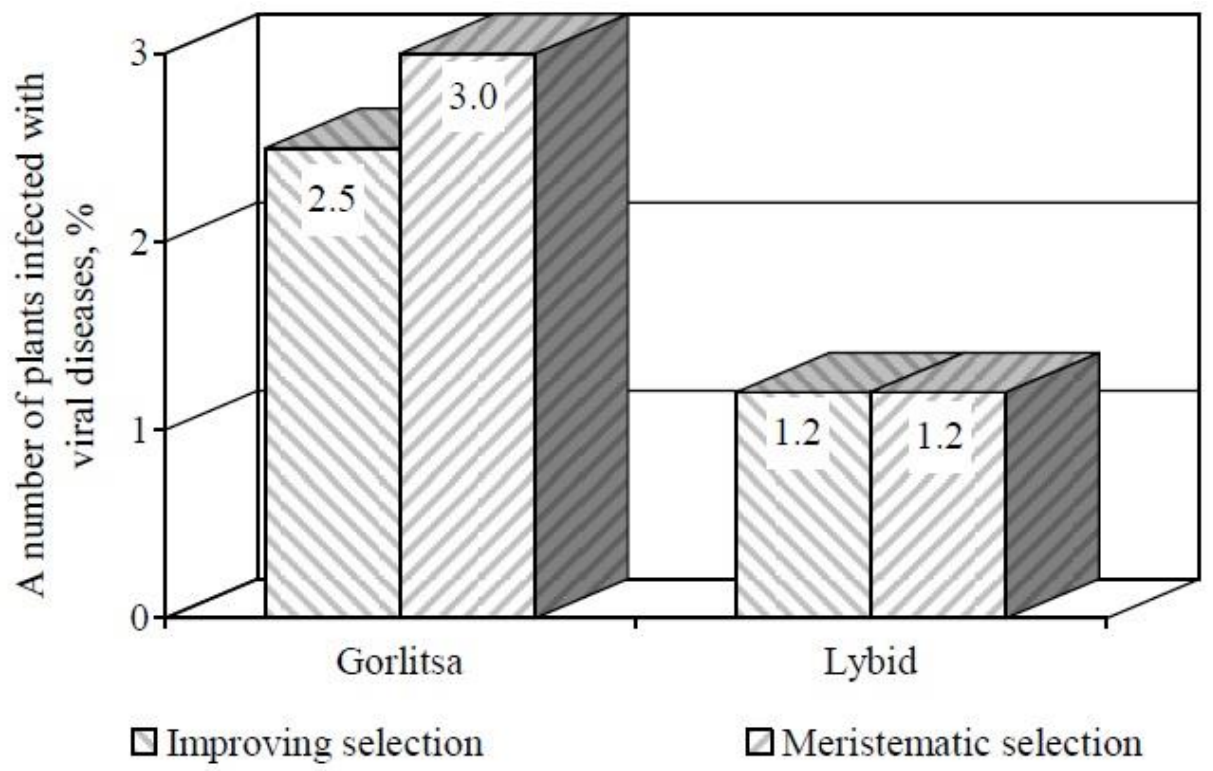

Figure 1. The infestation by viral diseases of seed material from varieties Gorlitsa and Lybid in 2016, \%.

In the year of testing, no significant difference in incidence of plantings by viruses for varieties Horlitsa and Lybid was found, depending on the method of obtaining the initial material for its recovery and the method of its formation. The meristem material was better compared with the obtained improvement selections: the difference in infestation of XBK, SBK and MBK was $2.2-3 \%$ for the variety Horlitsa and $1.2 \%$ for the variety Lybid. Regarding the infestation of plants with individual viruses, the most common virus was MBK, namely, from 27.8 to $55.5 \%$ in the variety Horlitsa, and from $12.0 \%$ to $16.0 \%$ in the variety Lybid (Table 1 ).

So, in the first year of seed material propagation obtained and formed in various ways, a significant factor regarding the presence of a viral infection in plantations is the variety, to a lesser extent, the method of forming the initial material. A certain pattern in the number of plants with signs of external manifestation of a viral infection in plantations of super-superelite varieties Horlitsa and Lybid, depending on the type of initial material and the method of its formation, have not been established. The total prevalence of plants on the plantations of the super-super-elite was insignificant, namely, within the requirements of the State Standard, the variety Horlitsa $-2.3-2.9 \%$, and the variety Lybid $-1.6-1.8 \%$. That is, the variety Lybid was noted for high quality indicators about the presence of plants with signs of viral diseases (Figure 2).

Table 1. The infestation of Gorlitsa and Lybid by XBK, SBK, MBK in the first testing year, \%.

\section{Initial material and method of formation}

Improving selection

Meristematic

propagation

Improving selection

Meristematic propagation

\section{Plants infected with viruses}

$\begin{array}{llll}\mathbf{S} & \mathbf{M} & \mathbf{X S}\end{array}$

Lybid

$0 \quad 6.0$

$$
0
$$

$$
0
$$$$
0
$$$$
0
$$

$\begin{array}{ccc}11.1 & 0 & 55.5 \\ 0 & 0 & 27.8\end{array}$

\section{Plants free from viruses}

\author{
84.0 \\ 88.0 \\ 44.5 \\ 72.2
}

In the plantations of super-superelite for two years of reproduction, there is also no significant difference in the incidence of seed material by XBK, SBK, MBK, depending on the type and method of the initial material formation. Concerning to plant infestation by individual viruses, MBK was most prevalent. On an ordinary material of the Lybid variety, this indicator was $32.0 \%$, and for the Horlitsa variety $-67.5 \%$. The meristem material was affected by this virus in the Horlitsa variety on $30.0 \%$ and in the Lybid variety on $26.0 \%$. The varieties Lybid wasn't affected by SBK. In both varieties that were tested, no plants affected by XBK were found. A significant advantage in favor of meristem and ordinary material is observed in the variety Lybid. Regarding latent viral infection, notably the presence of $\mathrm{XBK}, \mathrm{SBK}$ and $\mathrm{MBK}$, it is also not established a certain dependence of its presence on the different methods of obtaining and forming the initial material (Table 2). 


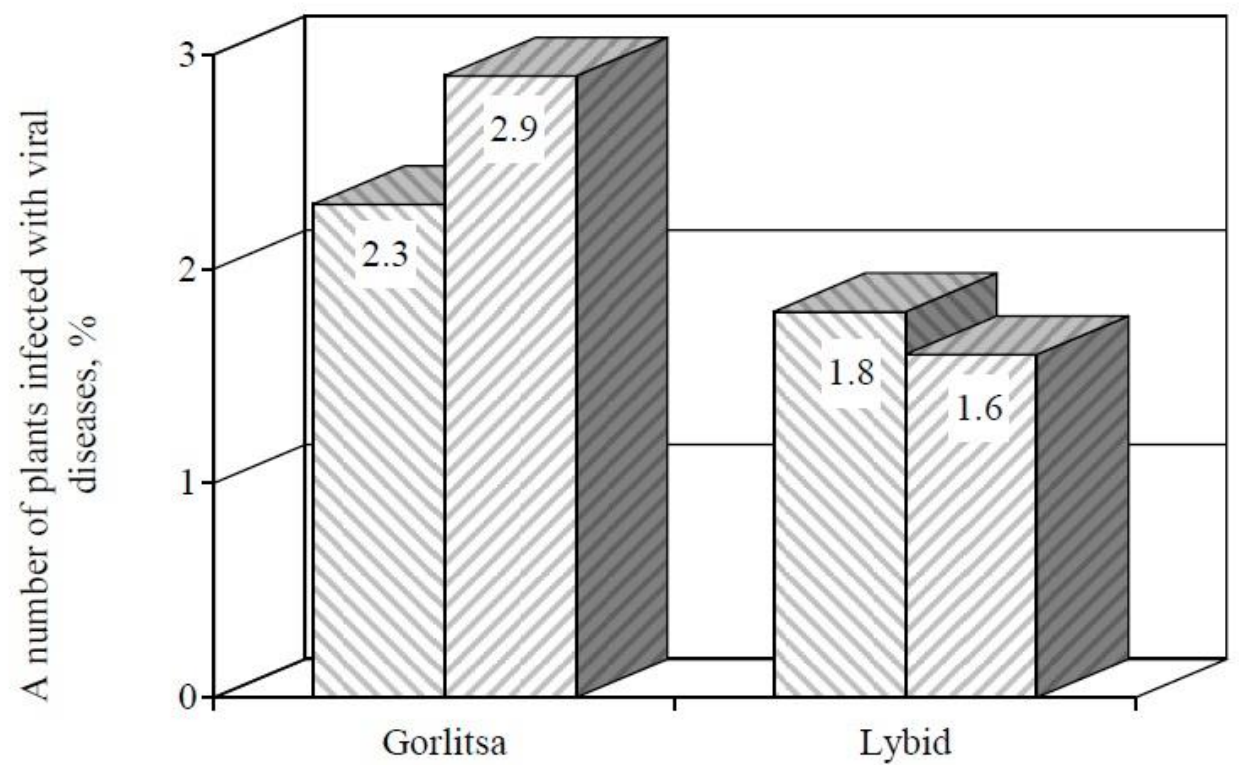

Improving selection

$\square$ Meristematic selection

Figure 2. The infestation of the super-super-elite seed material from varieties Gorlitsa and Lybid by viral diseases in $2017, \%$.

The general incidence of plants by XBK, SBK and MBK depended on the biological ability of varieties to resist a viral infection. For two years of reproduction of the initial material, the highest incidence of viruses was noted in the Horlitsa variety: $30.0 \%$ for meristem material and $67.5 \%$ for material from breeding nurseries. Our researches have not established a definite dependence on the number of plants with external signs of the viral infection manifestation, depending on the method of production and the method of forming the initial material. The plant incidence in the super elite, although slightly increased compared with the supersuper elite, however, did not exceed the requirements of the State Standard and amounted to 3.2\%-3.5\% for the variety Horlitsa and $2.5-2.7 \%$ for the variety Lybid (Figure 3 ).

Table 2. The infestation of varieties Gorlitsa and Lybid by XBK, SBK, MBK in plantations of super-super-elite (2017), \%.

\section{Initial material and method of formation}

Improving selection

Meristematic

propagation

Improving selection

Meristematic

propagation

\section{Plants infected with viruses}

X S

M

XS

$\mathbf{X M}$

SM

XSM

total

Plants free
from viruses

\section{Lybid}

$\begin{array}{lll}0 & 0 & 32.0\end{array}$

$$
0
$$

0

0

0

32.0

68.0

0

0

0

0

26.0

74.0

Gorlitsa

The difference in viral disease infestation between the first and third year of reproduction when using the material from the improving selections as the initial material was $1.2-2.7 \%$ for the variety Lybid and $2.5-3.2 \%$ for the variety Horlitsa. On the meristem material, the number of diseased plants for the relevant years of reproduction increased, depending on the method of its formation, in the variety Lybid from 1.2 to $2.5 \%$, in the variety Horlitsa from 3.0 to $3.4 \%$. The total number of plants with signs of external diseases manifestation over the years of reproduction depended on the biological characteristics of the variety to resist a viral infection. Our studies confirmed the production experiments of Kataev on the sowing qualities of potatoes in the scheme: superelite - elite - I - II - III reproduction, and showed significant varietal differences in the extent of plant infestation with viral diseases (Kataev, et al., 1995). In general, the prevalence of plants with viral diseases in the third year of reproduction of the initial material did not exceed the requirements of the State Standard for superelite. Evaluation of plants with the manifestation of viral diseases in them and the presence of viruses in a latent form showed that the accumulation of virus infection in potato plants over the years of reproduction does not significantly depend on the method of obtaining the initial material (improving selection during breeding, thermotherapy and apical meristem culture).

Regarding to the general infestation of seed material with viruses, it was higher in plantations with the initial material from breeding nurseries (Table 3). 


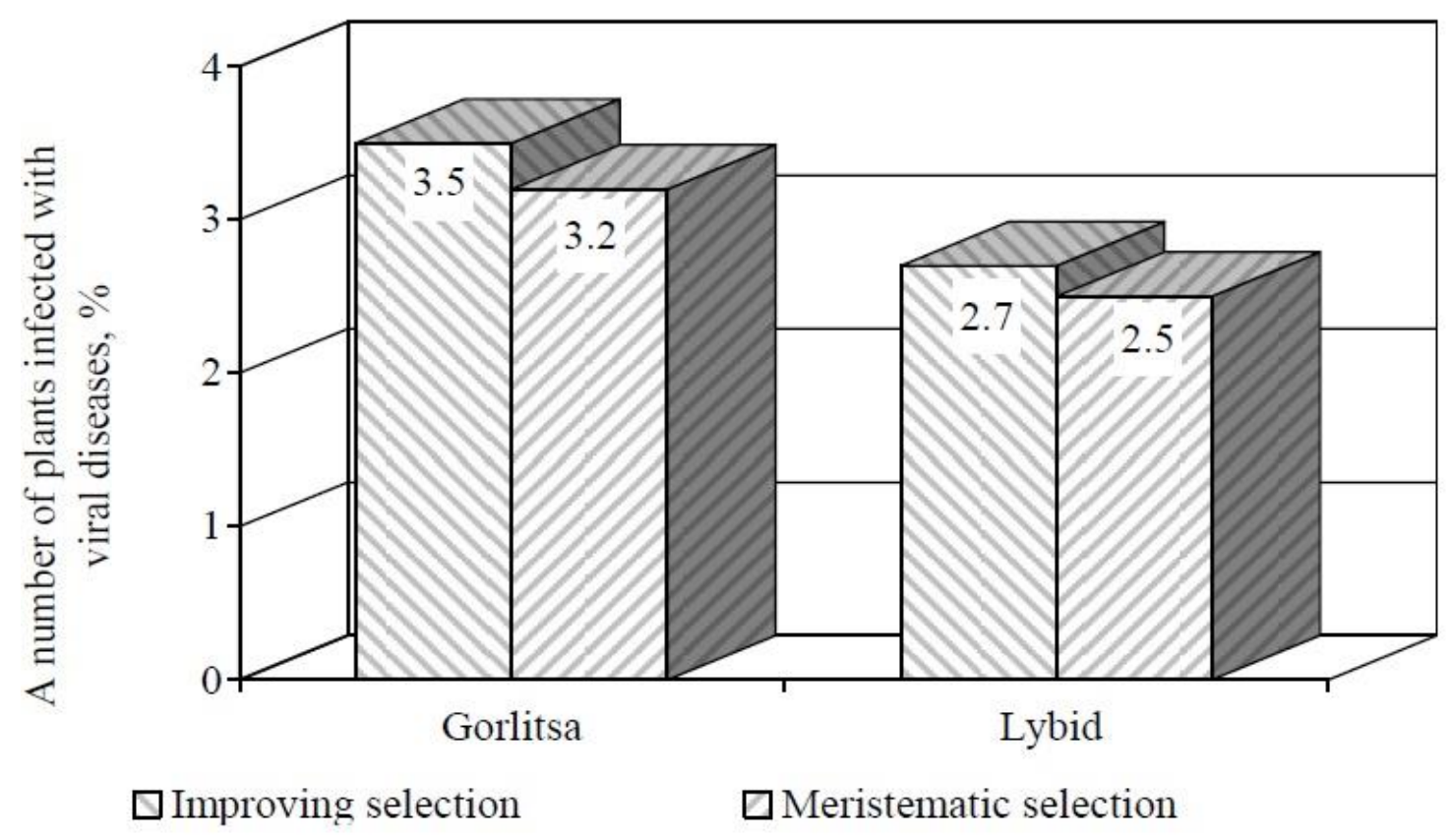

Figure 3. The infestation of the super-elite seed material from varieties Gorlitsa and Lybid by viral diseases in $2018, \%$.

The general prevalence of plants of $\mathrm{XBK}, \mathrm{MBK}$ and SBK depended on the biological characteristics of the variety to resist a viral infection. Thus, in the third year of reproduction, infestation seed material with viruses of the variety Lybid was 46.3-51.3\%. At the same time, over the three years of reproduction, the incidence of the Horlitsa variety by viruses was 32.5-65.0\%.

Table 3. The infestation of Gorlitsa and Lybid by XBK, SBK, MBK in plantations of super-elite in 2018, \%.

\begin{tabular}{|c|c|c|c|c|c|c|c|c|c|}
\hline \multirow{2}{*}{$\begin{array}{l}\text { Initial material } \\
\text { and method of } \\
\text { formation }\end{array}$} & \multicolumn{8}{|c|}{ Plants infected with viruses } & \multirow{2}{*}{$\begin{array}{l}\text { Plants free } \\
\text { from viruses }\end{array}$} \\
\hline & $\mathbf{X}$ & $\mathbf{S}$ & $\mathbf{M}$ & XS & $\mathbf{X M}$ & SM & XSM & total & \\
\hline $\begin{array}{l}\text { Lybid } \\
\text { Improving selection }\end{array}$ & 0 & 21.2 & 40.0 & 0 & 0 & 3.8 & 0 & 65.0 & 35.0 \\
\hline $\begin{array}{l}\text { Meristematic } \\
\text { propagation } \\
\text { Gorlitsa }\end{array}$ & 0 & 6.3 & 22.5 & 0 & 0 & 3.8 & 0 & 32.5 & 67.5 \\
\hline Improving selection & 0 & 6.2 & 36.2 & 0 & 0 & 3.7 & 0 & 46.3 & 53.7 \\
\hline $\begin{array}{l}\text { Meristematic } \\
\text { propagation }\end{array}$ & 0 & 12.5 & 36.2 & 0 & 0 & 2.5 & 0 & 51.3 & 48.7 \\
\hline
\end{tabular}

Regarding latent viral infection, namely the presence of $\mathrm{XBK}, \mathrm{SBK}$ and $\mathrm{MBK}$, also it is not established a certain dependence on its different methods of obtaining and forming the initial material.

As a result of our research, it was noted that with a general increase in viral infection since the time of the initial material reproduction, the intensity of its accumulation depends on the biological characteristics of the variety to resist viral infection and to some extent on the type of the initial material according to the production method (improving selection in nurseries for breeding, thermotherapy and culture of the apical meristem).

Tests of different seed material formed by the method of its production showed that meristem seed material (super-superelite) of the variety Horlitsa is more productive. Similar results were obtained at the Lybid variety - higher yield was noted in plantings, where material obtained by selections (Figure 4).

It is proved that the longer the time from inoculation to tuberization, the higher the risk of tubers infection with viruses. At the same time, not all tubers from one bush and even not all eyes of a single tuber can be affected (Zykin, 1976).

It has also been established that large tubers are more often affected by small ones, and the virus more often reaches the top than the umbilical cord of the tuber (Bemster, 1976). At the same time, in some cases no regularities were found regarding the presence of viruses in tubers of different mass and viral infection in the plant (Goncharenko et al., 1992).

Our research has shown that tubers with a size more than $60 \mathrm{~mm}$ prevailed in the yield of both varieties. They were in the variety Lybid $-66.0-72.0 \%$, and in the variety Horlitsa - 48.6-52.0\%. Tuber seed fraction in the variety Lybid was $24.7-29.0 \%$, and in the variety Horlitsa $-44.1-45.6 \%$. Tubers up to $30 \mathrm{~mm}$ had an insignificant amount $-3.3-5.0$ and 3.9-5.8\%, depending on the variety (Table 4). 


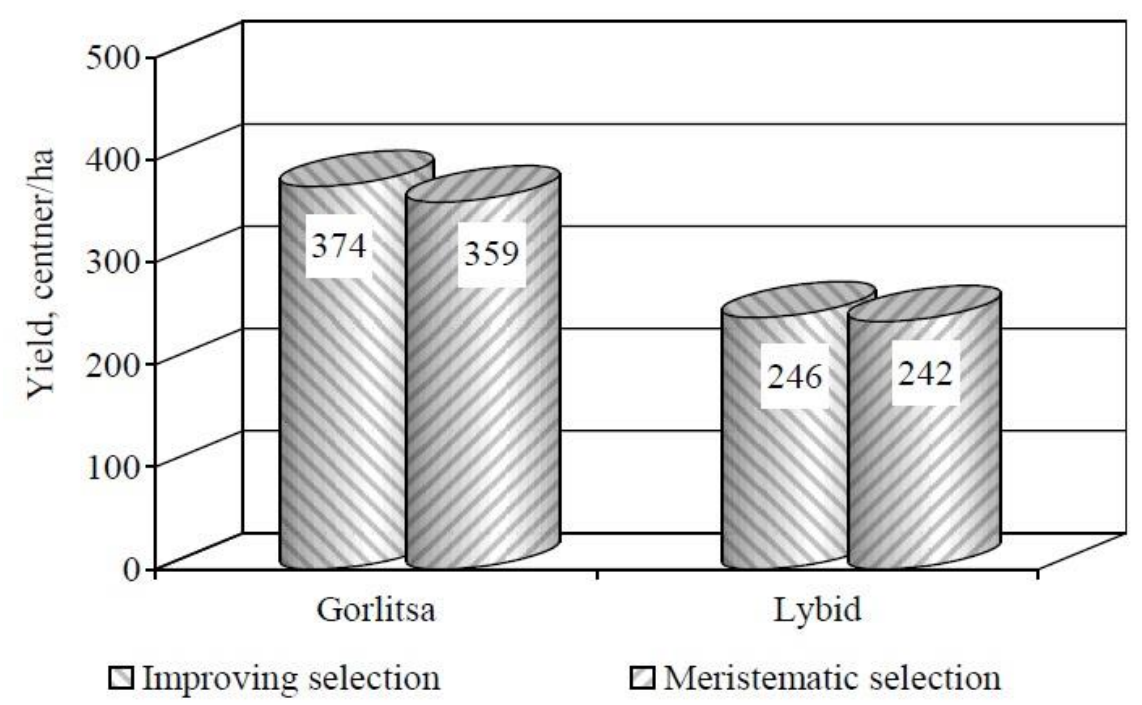

Figure 4. Yield, centner/ha of super-super-elite varieties Gorlitsa and Lybid (2017), Factor (A): LSD $05=7.4$ centner/ha Factor (B): $\operatorname{LSD}_{05}=7.4 \cdot 10^{2} \mathrm{~kg} \mathrm{ha}{ }^{-1}$, Factor $(A B): L D_{05}=10.5 \cdot 10^{2} \mathrm{~kg} \mathrm{ha}^{-1}$.

Table 4. Structural composition of the yield of super-super-elite varieties Gorlitsa and Lybid (2017), \%.

\begin{tabular}{|c|c|c|c|c|}
\hline \multirow{3}{*}{$\begin{array}{l}\text { Size of } \\
\text { tubers in } \\
\text { yield, } \mathbf{m m}\end{array}$} & \multicolumn{4}{|c|}{ Initial seed material } \\
\hline & \multicolumn{2}{|c|}{ Improving selection } & \multicolumn{2}{|c|}{ Meristematic propagation } \\
\hline & Gorlitsa & Lybid & Gorlitsa & Lybid \\
\hline$<30$ & 3.9 & 3.3 & 5.8 & 5.0 \\
\hline $30-60$ & 44.1 & 24.7 & 45.6 & 29.0 \\
\hline$>60$ & 52.0 & 72.0 & 48.6 & 66.0 \\
\hline
\end{tabular}

As a result of studies conducted in 2018 , it was found that the yield of the Lybid super-elite increased significantly compared with the previous year. We obtained the contrary results for the variety Horlitsa (Figure 5).

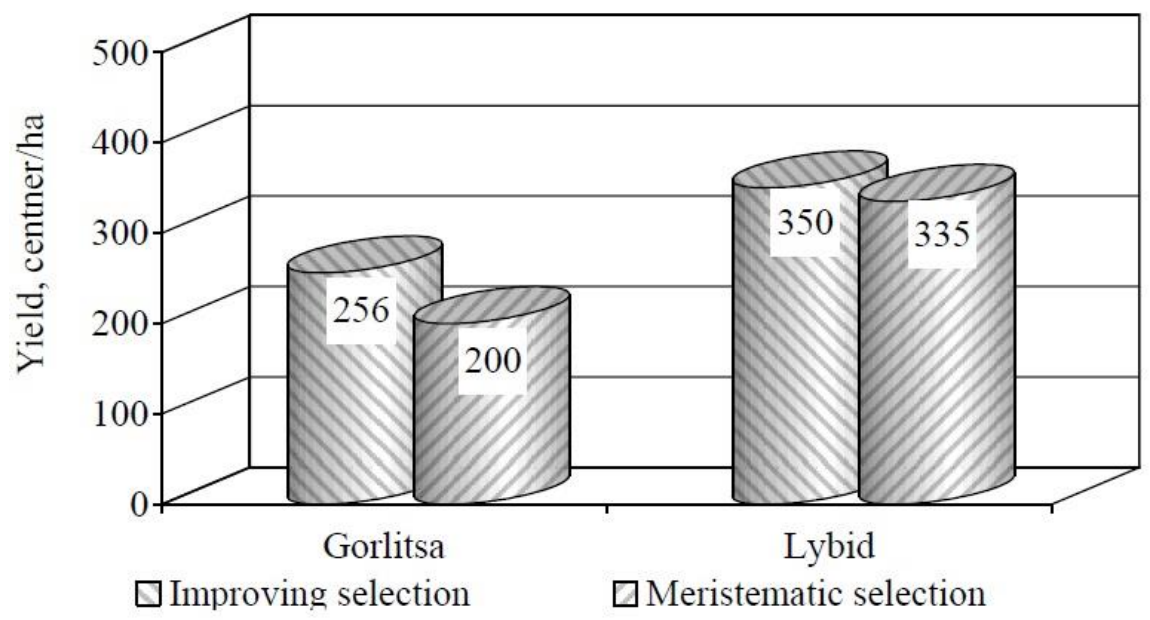

Figure 5. Yield of super-super-elite varieties Gorlitsa and Lybid (2018), centner/ha.

Factor (A): $\mathrm{LSD}_{05}=7.5 \cdot 10^{2} \mathrm{~kg} \mathrm{ha}^{-1}$

Factor (B): $\mathrm{LSD}_{05}=7.5 \cdot 10^{2} \mathrm{~kg} \mathrm{ha}^{-1}$

Factor (AB): $\mathrm{LSD}_{05}=10.6 \cdot 10^{2} \mathrm{~kg} \mathrm{ha}^{-1}$

It has been established that in plantations of Lybid variety superelite, which were carried out in areas of both selective breeding and in plantations of meristem material, the yield within the variety was not significantly different. At the same time, the variety Horlitsa had a slightly higher crop yield when using seeds from clonal propagation in breeding nurseries. The results of our research showed that in the structure of the crop there were no significant differences in the number of tubers of different fractions depending on the method of obtaining the initial material (Table 5). Tubers with a size $30-60 \mathrm{~mm}$ prevail in the harvest; their share is $45.1-56.4 \%$ of the total. Tuber sized more than $60 \mathrm{~mm}$ were mostly in the variety Horlitsa $-41.1-42.9 \%$, in the variety Lybid - 35.7-38.7\%. Thus, in our studies, a significant effect on the manifestation of a trait, both when growing super-super-elites and super-elites, has the weather conditions of the year and the biological characteristics of the variety. In 2017, more tubers of the seed fraction were noted in the variety Horlitsa $44.1-45.6 \%$, less - in the variety Lybid $24.7-29.0 \%$. In 2018, more tubers of the seed fraction were formed in the Lybid variety $-53.8-56.4 \%$, in the variety Horlitsa $-45.1-48.8 \%$. 
Table 5. Structural composition of the yield of super-elite varieties Gorlitsa and Lybid (2018), \%.

\begin{tabular}{|c|c|c|c|c|}
\hline \multirow{3}{*}{$\begin{array}{c}\text { Size of } \\
\text { tubers in } \\
\text { yield, } \mathbf{m m}\end{array}$} & \multicolumn{4}{|c|}{ Initial seed material } \\
\hline & \multicolumn{2}{|c|}{ Improving selection } & \multicolumn{2}{|c|}{ Meristematic propagation } \\
\hline & Gorlitsa & Lybid & Gorlitsa & Lybid \\
\hline$<30$ & 12.0 & 7.9 & 10.1 & 7.5 \\
\hline $30-60$ & 45.1 & 56.4 & 48.8 & 53.8 \\
\hline$>60$ & 42.9 & 35.7 & 41.1 & 38.7 \\
\hline
\end{tabular}

\section{Conclusions}

1. We proved that the yield of super-super-elite of Lybid variety is not significantly changed depending on the method of obtaining the initial material. The variety Gorlitsa has higher yield in the plantations formed by clonal propagation.

2. We established that the yield of variety Lybid super-elite varies, but not significantly, depending on the method of obtaining the initial material. The variety Gorlitsa has a higher super-elite yield when using the initial material from clonal propagation in breeding nurseries with use of improved selections.

3. Significant influence on the manifestation of the sign, both in the cultivation of super-super-elites and super-elites, has the weather conditions of the year and the biological characteristics of the variety.

4. In 2017, the highest yield of tubers was obtained at Gorlitsa $-3.74 \cdot 10^{4} \mathrm{~kg} \mathrm{ha}^{-1}$, at Lybid the yield was $2.43 \cdot 10^{2} \mathrm{~kg} \mathrm{ha}^{-1}$. In 2018 , the highest yield of tubers was formed at Lybid variety $-3.50 \cdot 10^{2} \mathrm{~kg} \mathrm{ha}^{-1}$ and the lowest at Gorlitsa variety $-2.56 \cdot 10^{2} \mathrm{~kg} \mathrm{ha}{ }^{-1}$.

\section{References}

Afonnikov D.A., Totsky I.V., Stasevski Z. (2018). Informational resources on potato germplasm collections. Vavilovskii Zhurnal Genetiki i Selektsii=Vavilov Journal of Genetics and Breeding, 22(1), 115-121. DOI 10.18699/VJ18.330

Ambrosov A.L. (1975). Viral diseases of potatoes and a measure to combat them. Minsk: Urodzhai. (in Russian).

Baranova V.K., Kurlovich M.M., Burova V.V. (1990). On the production patterns of elite on a meristem basis. Biotechnology-based potato breeding and seed farming, 24-31. (in Russian).

Bemster B. (1976). Movement of the virus in potato plants and age-related resistance. Viral diseases and potato seed production. Moscow. Kolos. (in Russian).

Blotskaya J.V. (1983). Viral diseases of potatoes. Minsk: Nauka and Technica. (in Russian).

Chesnokov P.G. (1960). Diagnosis of viral diseases of potatoes. Viral diseases pp. plants and measures to combat them. Moscow. Publishing House of the USSR Ministry of Agriculture. (in Russian).

Dospekhov, B.A. (1985). Methods of field experiment (with the basics of statistical processing of research results). (5th ed., rev.). Moscow, Agropromizdat. (in Russian).

Erenkova L.A., Molyavko A.A., Marukhlenko A.V., Borisova N.P. (2018). New generation potato varieties with resistance to pathogens. Selektsiya, semenovodstvo i genetika, 4(22), 47-50. DOI 10.24411/2413-4112-2018-10007

Frolova M.I. (1971). Are signs of degeneracy disappearing, whether they are permanent. Uzhgorod: Carpathians. (in Russian).

Gavrilenko T.A., Klimenko N.S., Antonova O.Yu., Lebedeva V.A., Evdokimova Z.Z., Gadjiyev N.M., Apalikova O.V., Alpatyeva N.V., Kostina L.I., Zoteyeva N.M., Mamadbokirova F.T., Egorova K.V. (2018). Molecular screening of potato varieties bred in the northwestern zone of the Russian Federation. Vavilovskii Zhurnal Genetiki i Selektsii=Vavilov Journal of Genetics and Breeding, 22(1), 35- 45. DOI 10.18699/VJ18.329

Goncharenko O.P., Nechiporenko G.T., Martyshchenko O.P. (1992). Productive and seed quality of potatoes of the Gart and Call variety, depending on the mass of planting tubers and density of sable plants. Potatoes, 23, 37-40. (in Russian).

Ibragimova S.M., Romanova A.V., Myzgina G.Kh., Kochetov A.V. (2018). The morphogenic potential of Siberian potato cultivars in tissue cultures. Vavilovskii Zhurnal Genetiki i Selektsii =Vavilov Journal of Genetics and Breeding, 22(3), 316-320. DOI $10.18699 / \mathrm{VJ} 18.366$

Khan, M.A., Munive, S. \& Bonierbale, M. (2015). Early generation in vitro assay to identify potato populations and clones tolerant to heatPlant Cell Tiss Organ Cult, 121, 45. DOI https://doi.org/10.1007/s11240-014-0677-z

Khodaeva V.P., Kulikova V.I. (2016). Breeding of potato varieties in culture in vitro on different culture media. Achievements of science and technology of agriculture, 10(30), P. 66-68.

Kim, I.V., Novoselov, A.K., Novoselova, L.A., Voznyuk, V.P. (2016). Puti povysheniya ehffektivnosti proizvodstva kartofelya (Ways to Improve Potato Productive Efficiency). Vestnik of the Russian Agricuture Science, 5, 11-13 (in Russian).

Kisilev V.N., Nazarenko V.I., Solomina I.P. (1990). Tissue culture in potato seed farming. Potato farming abroad. Moscow. VNIITEI agroprom. (in Russian).

Kononuchenko, V. V. (2012). Methodical recommendations for conducting researches with potatoes. Nemishaive. (in Russian).

Loginova G.A. (1986). Potato variety Nevsky in primary seed production. Selection, seed production and technology of growing potatoes in the North-West of the RSFSR. Leningrad. (in Russian).

Maishchuk Z.M. (1995). Modern aspects and problems of potato breeding on field viral resistance. Problems of breeding and seed potatoes in the western region of Ukraine. Lviv (in Russian).

Maishchuk Z.M., Sadovsky M.Ya. (1995). Cultivation of visual-serological method of seed potato material recovered in conditions of Lviv region. Problems of breeding and seed production of potatoes in the Western region of Ukraine. Lviv (in Russian).

Makarova S.S., Makarov V.V., Taliansky M.E., Kalinina N.O. Resistance to viruses of potato: current status and prospects. Vavilovskii Zhurnal Genetiki i Selektsii=Vavilov Journal of Genetics and Breeding. 2017;21(1):62-73. DOI 10.18699/VJ17.224

Mayshchuk Z.N. (1991). Clonal propagation is needed. Potatoes and vegetables, 5, 39-41. (in Russian).

Mohapatra P.P., Batra, V.K. 2017. Tissue Culture of Potato (Solanum tuberosum L.): A review. Int.J.Curr.Microbiol.App.Sci. 6(4): 489-495. DOI https://doi.org/10.20546/ijcmas.2017.604.058

Onishchenko O.Y. (1996). Seed potatoes in Ukraine. Kiev (in Russian).

Ostapenko D.P. (1990). Methods of obtaining the source material in the seed potatoes. Potatoes. Kiev Urozhay. (in Russian). 
Ovjes E. V., Gaitova N.A. (2006). New technology elements and basic clones of promising varieties and hybrids of potato. Achievements of science and technology of agriculture, 11(30), 60-62. (in Ukrainian).

Potatoes. (2002). Kononuchenko, V.V., Molotsky, M. Ya (Eds.). pp. 1-535. Bila Tserkva (in Russian).

Reyfman V.G., Gnutova R.V., Romanova S.A. (1996). Physiological and biochemical properties of viruses affecting potatoes, and methods of rehabilitation of seed material in the Far East. Plant biology, 3, 93-106. (in Russian).

Riznyk V.S. (1997). Improvement of potato: Problems and perspectives, Potato growing. Kiev. Naukova Dumka, 27, 23-34. (in Russian).

Rogozina E.V., Khavkin E.E. (2017). Interspecific potato hybrids as donors of durable resistance to pathogens. Vavilovskii Zhurnal Genetiki i Selektsii=Vavilov Journal of Genetics and Breeding, 21(1), 30-41. DOI 10.18699/VJ17.221

Saynakova A.B., Romanova M.S., Krasnikov S.N., Litvinchuk O.V., Alekseev Ya.I., Nikulin A.V., Terentjeva E.V. (2018). Testing potato collection samples for the presence of genes for resistance to phytopathogens by means of DNA markers. Vavilovskii Zhurnal Genetiki i Selektsii=Vavilov Journal of Genetics and Breeding, 22(1), 18-24. DOI 10.18699/VJ18.326

Sheludko Yu.M. (1970). Fitovirusology. Kiev. Vysshaya shkola (in Russian).

Shmygl V. (1989). Biological substantiation, development and improvement of methods for diagnosing viruses in the breeding and seed production of potatoes and tomatoes. Thesis of Doctoral Dissertation. Leningrad. (in Russian).

Shmygl V. (1995). How to improve the planting material of potatoes. Protection of plants, 2, 19-20 (in Russian).

Svertoka V.E. (1993). Influence of output for propagation of seed clones on the quality and productivity of super-superlattice of potato. Kartoplyarstvo, 24, 41-44 (in Ukrainian)

Svertoka V.YE. (1998). Main effects of research on potato seed production in Ukraine. Potato growing, 28, 14-18. (in Russian).

Trifonova E.A., Ibragimova S.M., Volkova O.A., Shumny V.K., Kochetov A.V. (2018). Ribonuclease activity as a new prospective disease resistance marker in potato. Vavilovskii Zhurnal Genetiki i Selektsii = Vavilov Journal of Genetics and Breeding. 2018;22(8):987ᄀ991. DOI 10.18699/VJ18.441

Trofimets L.N. (1989). Biotechnology in potato. Moscow. (in Russian).

Trofimets L.N. (1990). Viral diseases of potatoes. Moscow. Agropromizdat. (in Russian).

Tymoshenko I.I., Maishchuk Z.M., Konovalyuk M.G., Dobrovolsky R.S. (1991). Prospects of primary seed production of phytophthora resistant potato varieties. Bulletin of Agrarian Science, 4, 36-39. (in Russian).

Vakhnyi S., S. Vakhnyi, V. Khakhula, Y. Fedoruk, T. Panchenko, L. Herasymenko, L. (2018). The efficiency increase of the nutrition element uptake by various potato cultivars grown in one-crop system and in crop rotation. EurAsian Journal of BioSciences, $12,1-7$. Vermenko Yu.Ya. (1992). The reaction of new zoned potato varieties for rejuvenation. Potato growing, 23, 55-59. (in Russian). Vermenko Yu.Ya., Svertoka V.E. (1988). Reproduction of the elite of potatoes. Selection and seed potatoes. Kiev. Urozhay. (in Russian).

Zykin A.G. (1976). Viral diseases of potatoes. L.eningrad. Kolos. (in Russian).

\section{Citation:}

Fedoruk, Y., Grabovskyi, M., Pravdyva, L., Ostrenko, N., Lozinska, T., Fedoruk, N., Grabovska, T., Obrazhyy, S., Hornovska, S., Prisjazhnjuk, N. (2020). Analysis of potate quality: in vitro versus clonal propagation. Ukrainian Journal of Ecology, 10(1), 106-113. 